\title{
IAMJ
}

INTERNATIONAL

AYURVEDIC

MEDICAL JOURNAL

Review Article

ISSN: 2320-5091

Impact Factor: 6.719

\section{COMPREHENSIVE STUDY OF NABHI IN BRUHATRAYI AND ITS CORRELATION WITH MODERN SCIENCE}

\section{$\underline{\text { Shipra Katiyar }}$}

Associate professor, department of Rachna Sharir,

Shri Babu Singh Daddu Ji Ayurvedic Medical College, Farrukhabad, Uttar Pradesh, India

Corresponding Author: smilingface2004@gmail.com

\section{https://doi.org/ $10.46607 /$ iamj12p5032021}

(Published online: March 2021)

Open Access

(C) International Ayurvedic Medical Journal, India 2021

Article Received: 13/03/2021 - Peer Reviewed: 15/03/2021 - Accepted for Publication: 17/03/2021

Check for updates

\section{ABSTRACT}

Ayurveda is an intricate and detailed science, which provides great insight into the importance of every part of the body. One of the most important part is Nabhi. The Nabhi plays the most important role in development of body from the very beginning of life even at the embryonic stage. In ancient Indian tradition, the navel of the god Vishnu is consider as the center of the universe and the source of life. From his navel, a new world emerges. It not only has aesthetic importance but also tells the health status. It is a site of various treatments too which makes it worthy to consider its anatomical concepts and applied aspects. The literary review of Nabhi and modern studies suggest it as umbilicus.

Keywords- Nabhi, Marma, Sira, umbilicus

\section{INTRODUCTION}

'The navel is the core of everything about the person'

Japanese spiritualist Hogen Fukunaga

Nabhi is a term of varied importance. Etymologically the word Nabhi is derived from "nah bandhe" which means to bind or tie to the central point just like the spokes of wheel held at the nave. Nabhi has been represented throughout history as a sign of youth and beauty. The appearance of the Nabhi expresses about 
the life of the person. Samudrika Shastra, part of the Vedic tradition, is also one of the themes incorporated into the ancient Hindu text, the Garuda Purana, describes one's destiny according to shape of Nabhi too. Those who have got fish-like bellies and navels, become happy. Those, who have got capacious or low navels, are doomed to suffer miseries. If there is wrinkle inside a navel it brings on death at the stake for the person. If there is wrinkle on one side the man lives for ever. If it is in an equinoctial position, he becomes the possessor of riches. If it is downwards, he becomes the possessor of kine. It is of the shape of a pericarp of a lotus he becomes a king. If there is one wrinkle the person lives for a hundred years. If there are two, he enjoys prosperity. If there are three wrinkles, he becomes a preceptor. This science of reading bellybutton and analyzing personality is termed as Omphalomancy.

In yoga, the navel is the site of the Manipura (also called Nabhi) chakra, the contemplation of one's navel as an aid to meditation is known as navel gazing or omphaloskepsis. According to modern anatomy these Chakra can be understood to be formed by the part of autonomic nervous system. Located at the navel Manipur Chakra is said to be the seat of Agni within the body and has control on several functions of digestive system.

The term omphalos in Greek or umbilicus in Latin means a 'navel', which is a conical stone that was deemed in antiquity to have marked a 'Centre of the Earth'. It has been estimated that $30 \%$ of births have some type of umbilical cord finding. These disorders range from the very common umbilical hernia to infections such as omphalitis, which can be life threatening.

Trans umbilical endoscopic surgery or laparo-endoscopic single site (LESS) surgery has become an exciting area of surgical development as innovation continues to move in the $21^{\text {st }}$ century to minimally invasive surgery. The fundamental idea is to have all of the working ports entering the abdomen through a single incision, which could have better cosmetic results and fewer traumas. It is estimated that $50 \%-80 \%$ of traditional laparoscopic surgery could be performed trans umbilically in the next five years according to the LESSCAR consensus.

An understanding of the anatomy and embryology of the umbilicus is important to identify and properly treat common as well as rare complicated conditions. The knowledge of Sharir is spread all over the Samhitas and cannot be found in isolated forms like that of modern anatomy and physiology. These all factors naturally draw attention to know more about this point of abdomen in detail and emphasis on scope of future work on local treatment in umbilical region or Nabhi Chikitsa.

Aim: To study Nabhi in Bruhatrayi and its correlation with modern science.

\section{Objectives:}

1. To study anatomical and applied aspect of Nabhi in Bruhatrayi.

2. To compare Nabhi with the modern anatomy.

Methodology: The data has been collected and reviewed from Charak Samhita, Sushruta Samhita and Ashtang Hrudaya, other validated textbooks and publication.

\section{Review of Literature}

There are scattered references of Nabhi in all three Bruhatrayi.

\section{Anatomical aspect}

"Gambhirsvarnabhi" is the feature of Dirghayu. According to Acharya Charak, the Nabhi, which is curl towards left, deep in mid with elevated edges symbolises Dirgha ayu. ${ }^{1}$

During embryonic life, Nabhi gets develop from Matraj bhav.

In Charak Samhita, according to Acharya Bhadrakapya, Nabhi is first organ to develop in foetus as the foetus gets nutrition through Nabhi but in Sushruta Samhita, according to Acharya Parashar Nabhi is first organ to develop during embryonic life.

Acharya Sushruta states that Nabhi is located in between Amashay and Pakwashay. ${ }^{2}$

It is one of the fifteen Koshtang and Pratyang.

Nabhi is said to be a Prabhavasthana, i.e. a Dhamanis and a Sira site of origin. Siras feeds the foetus through Nabhinadi (umbilical cord) in foetal life. After birth, these Siras no longer exist. Acharya Sushruta therefore 
called them 'Nabhiprabhava.' As regards the relationship between Siras and Nabhi, Acharya Sushruta established that Nabhi-related Siras had spread throughout the human body. The Prana of the person is present in the Nabhi, and the Prana concerns the Nabhi itself. The Nabhi is surrounded by Siras like spokes from the centre of the wheel on all sides. In Sushruta Sharirsthan, it was outlined that Siras from the Nabhi spread throughout the body just as water spreads from the lotus plant rhizome to the lotus flower stalk. Acharya Sushruta said in Sharirsthana 3rd chapter that the Nabhinadi remains attached to the foetus Rasavahanadi and this Nabhinadi carries Ahararasavirya (nutrition) from the mother to Garbha. ${ }^{3}$

The science of Ayurveda described Marmas with immense importance as critical sites that can cause serious ill effects on individual health. Nabhimarma is one among the 107 Marmas explained in the science. If injured, it can lead to immediate death or death within 7 days. It is single in number, belonging to the abdominal region. This Marma is structurally made of Sira, and is of one's own palm size in area (4 Angulas)

Acharya Charak also enumerate it under Das pranayatanas.

\section{Physiological aspect}

Nabhi is seat of Udan and Apan Vayu. According to Acharya Vagbhat, it is the main site of Pitta Dosha.
Nabhi being as a centre of Agni; or a dominant place of Pitta with the help of Samana Vayu located at Nabhi perform the process of digestion through Grahana (consumption / selection), Pachana (conversion), Vivechana (separation) and Munchana (give up for next stage). ${ }^{4}$

\section{Clinical Aspect}

1. Nabhi Naal Kartan Janya Vyadhi - Acharya Charaka described Nala Chedana to be undertaken after Pranapratyagaman. After fixing the point at eight figures from umbilical attachment, the cutting point should be held tightly on both sides and cut with a sharp half-edged instrument made of gold, silver or steel. The end of the attached portion should be tied with thread and attached loosely to the neck of the foetus. If the cut portion suppurates, it should be massaged with the oil prepared with the paste of Lodhra (Symplocos recemosa), Madhuka (Glycyrrhiza glabra), Priyangu (Callicarpa macrophylla), Devdaru (Cedrus deodara), and Haridra (Curcuma longa). The powder of the above drugs may also be applied over the part.

If umbilical cord cutting is not handled or treated properly or there is any fault in umbilical cord care practice it can lead to different complications called as Nabhi Upadrava. [Table no.1]

Table 1: Nabhi Naal Kartan Janya Vyadhi

\begin{tabular}{|l|l|}
\hline Nabhi Naal Kartan Janya Vyadhi & Chikitsa \\
\hline Unnata Nabhi (distended umbilicus) & Application of goats' dunk ash on Nabhi \\
\hline Anunnata Nabhi (depressed umbilicus) & $\begin{array}{l}\text { Application of goat or sheep dunk ash along with Ashwagandha, Anjana and Yas- } \\
\text { timadhu Churna }\end{array}$ \\
\hline
\end{tabular}

Acharya Sushruta in Sharirasthan describe Nabhi tundi as Adhman (distension) of Nabhi due to Vayu associated with pain.

2. Nabhi Vidradhi - It is the type of Antahvidradhi. Its clinical feature is Hikka. According to Acharya Sushruta, it is also associated with Atopa. If it gets suppurated will cause death.

3. Nabhi Vrana- According to Acharya Sushruta the Vrana that is located on Nabhi is Duschikitsiya.
4. Nabhi Arsha-Arshas which originated from Nabhi are like earthworm shape, soft, slimy.

5. Site of Gulma.

6. Vayu located in Pakwashay causes pain in Nabhi.

7. Hikka, which develops from Nabhi, is known as Gambhira Hikka. 


\section{DISCUSSION}

During embryonic life, Nabhinadi (umbilical cord) remains attached to the foetus Rasavahanadi and this Nabhinadi carries Ahararasavirya (nutrition) from the mother to Garbha. When the baby born, this Nabhi nadi/ naal is cut and remnant scar is known as Nabhi. In modern science, the normal scar in anterior abdominal wall formed by the remnants of the root of umbilical cord is known as umbilicus.

The position of umbilicus is variable. In healthy adults, it lies in the anterior median line, at the level of L3 and L4 vertebrae. When abdominal distension is present from any cause, the umbilicus may become flattened or even everted. In obese, the umbilical cleft is deeper than normal.

The root of Sira and Dhamani is Nabhi. It can be explained only with the help of embryology. Sira and Dhamani in Ayurveda represent the vascular system of the body, which includes the arteries and veins. Embryological development shows that it is the meeting point of three systems, namely the digestive, excretory (urachus) and vascular (umbilical vessels). The umbilicus is one of the important sites at which tributaries of the portal vein anastomose with systemic veins (portal anastomoses). In portal hypertension, these anastomoses open up to form dilated veins radiating from the umbilicus called the caput medusa (fig.1). It is in accordance with the anatomy described by our acharyas. ${ }^{5}$ In nine region of abdomen, umbilical region lies in the centre. Its content is aorta, inferior vena cava, coils of small intestine and stomach. Marma Sthana of Nabhi can be ascertained in the umbilical region of abdomen within the 4 Angula circumference and depth. As per dissection, it is observed that is not an organ but a region under which many neurovascular, visceral and skeletal structures are present. Being the vascular structures coming under the umbilical region are vital. The abdominal aorta, inferior vena cava, superior mesenteric artery with its branches, anastomosis between superior epigastric and inferior epigastric arteries, are clinically vulnerable. The direct penetrating injury to these vascular structures will lead to internal haemorrhage and shock.

The midgut forms the primary intestinal loop, from which originates the distal duodenum to the entrance of the bile duct. The loop continues to the junction of the proximal two-thirds of the transverse colon with the distal third. At its apex, the primary loop remains temporarily in open connection with the yolk sac through the vitelline duct. During the sixth week, the loop grows so rapidly that it protrudes into the umbilical cord (physiological herniation). In the $10^{\text {th }}$ week, it returns into the abdominal cavity. ${ }^{6}$

Duodenum/ Grahani, the seat of Agni responsible for digestion whereas jejunum and ileum are responsible for the absorption. The nerve supply of small intestine is sympathetic (T9 to T11) as well as parasympathetic (vagus), both of which pass through the celiac and superior mesenteric plexuses.

The nerves from the myenteric plexus of Auerbach, containing parasympathetic ganglia between circular and longitudinal muscle coat. Fibres from this plexus form the sub mucous plexus of Meissner, which also contains parasympathetic ganglia. Sympathetic nerves are motor to the sphincters and to the muscularis mucosae and inhibitory for peristaltic movements. The parasympathetic nerves stimulate peristalsis but inhibit the sphincters.

The nerve plexuses and neurotransmitters of the gut are quite complex. These are called the enteric nervous system (ENS, the "brain of the gut")

Since, it is the site for the digestive process, the Ahara ras formed is responsible for the Bala, Varna, Oja. It is also the function of Udan Vayu, which is located in Nabhi. It signifies the importance of local application of oil and ghrita for glowing skin.

Clinical correlation with modern science is done in table no. 2 and fig. 2 
Table 2: Ayurvedic terms related with modern entities

\begin{tabular}{|l|l|l|}
\hline a) & Nabhi Paak & Omphalitis \\
\hline b) & Nabhi Vidradhi & Umbilical abscess \\
\hline c) & Nabhi Arsha & Umbilical granuloma \\
\hline d) & Nabhi Vrana & Umbilical ulcer due to neoplasm \\
\hline e) & Nabhi Tundi & Umbilical hernia \\
\hline f) & Nabhi Ruja & Periumbilical pain \\
\hline
\end{tabular}

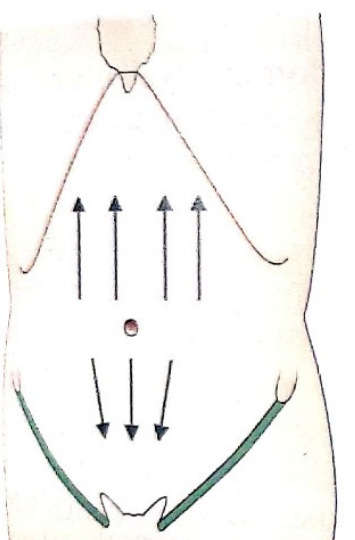

Fig. 1 a

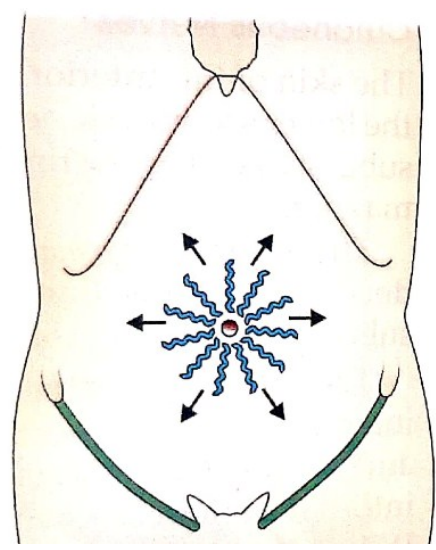

b

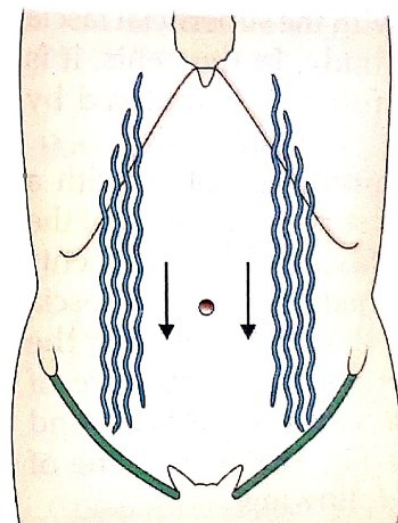

c

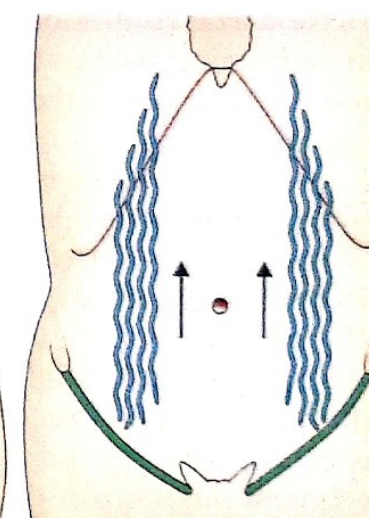

d

Figure 1 a to d: The subcutaneous venous circulation in (a) normal subjects, (b) portal obstruction showing caput medusa, (c) superior vena caval obstruction, (d) inferior vena caval obstruction (arrows indicate the direction of blood flow.

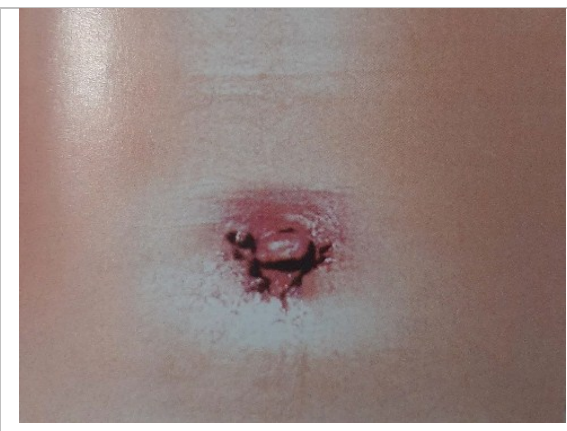

a) Nabhi Paak / Omphalitis

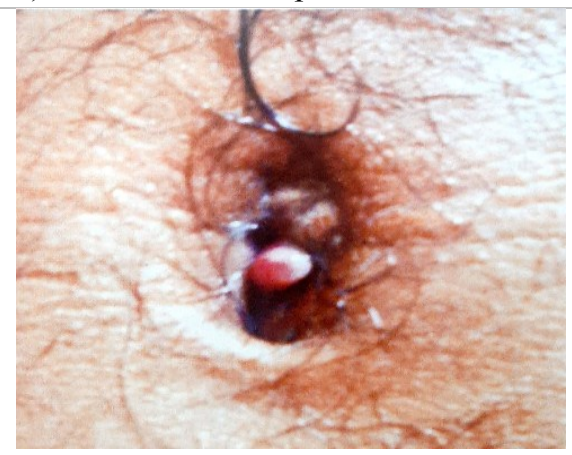

c) Nabhi Arsha / Umbilical granuloma

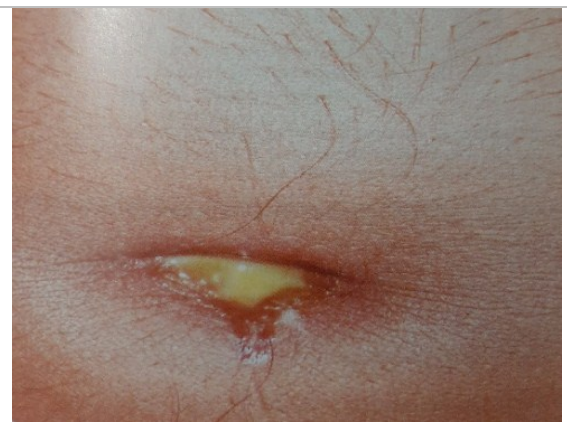

b) Nabhi Vidradhi / Umbilical sepsis

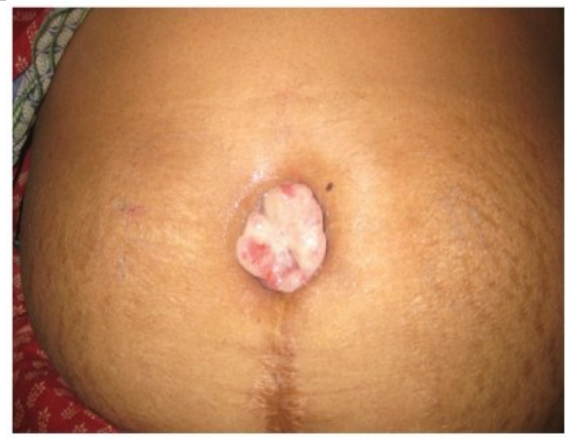

d) Nabhi Vrana / Umbilical ulcer 


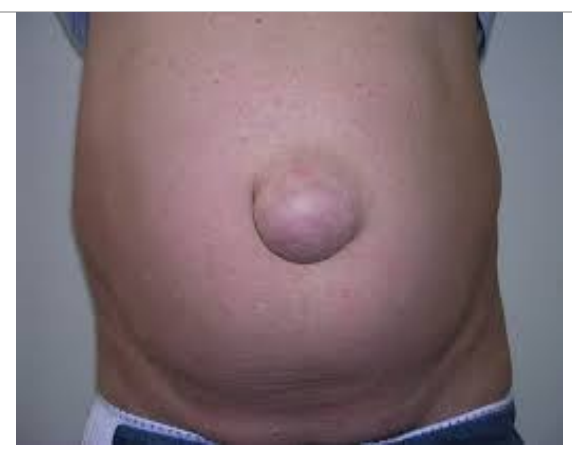

e) Nabhi Tundi / Umbilical hernia

Figure 2: Ayurvedic terms and their modern entities

\section{CONCLUSION}

A healthy gut is integral to healthy skin

Nabhi plays an important role from ancient time to present era. From our ancestors, its tradition of applying Hinga in periumbilical region in infants while crying, applying oil or Ghrita locally. In present era, in modern science, umbilicus is an excellent site for primary access to the peritoneal cavity during laparoscopic surgery. Embryological development shows that it is the meeting point of three systems, namely the digestive, excretory (urachus) and vascular (umbilical vessels). Anatomical, physiological and applied aspect described in Bruhatrayi clearly states Nabhi as umbilicus. It paves a way for more research to be carried on Nabhi Chikitsa.

\section{REFERENCES}

1. Charak Samhita by Dr. Gorakh Nath Chaturvedi, vol -1, Edited by- Rajeswaradatta sastri, Charak Samhita sharira sthan chapter-8, verse- 51, Edition 2005, published by Chaukhambha Bharti Academy.

2. Sushruta Samhita by Kaviraja Ambikadutta Shastri, vol1, edited by Ayurveda Tattva Sandipika, Sushruta Samhita sharira sthan chapter-6, verse- 26, Edition 2007, published by Chaukhambha Sanskrit Sansthan, Varanasi.

3. Sushruta Samhita by Kaviraja Ambikadutta Shastri, vol1, edited by Ayurveda Tattva Sandipika, Sushruta Samhita sharira sthan chapter-3, verse- 29, Edition 2007, published by Chaukhambha Sanskrit Sansthan, Varanasi.

4. Ashtangahrudaya Samhita by Kaviraj Atridev Gupta, edited by - Vaidya Yadunandan Upadhyaya, Ashtang
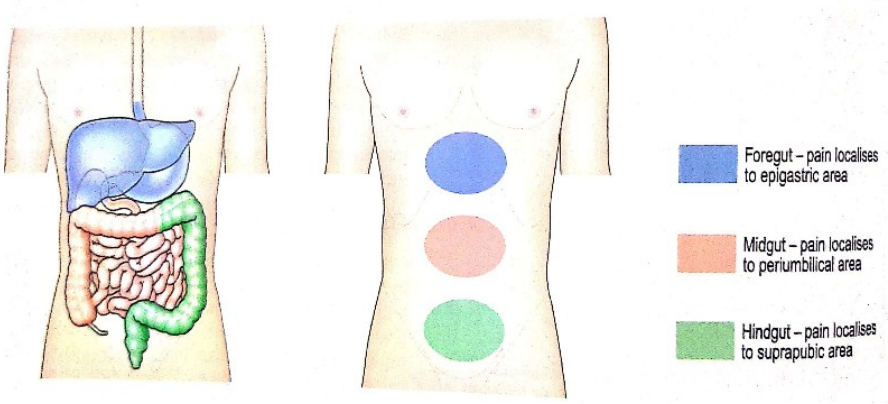

f) Nabhi Ruja/ Periumbilical pain
Hrudaya Samhita Sutrasthan chapter-12, verse- 2,8, Edition 2009, published by Chaukhambha Prakashan, Varanasi.

5. Human anatomy by BD Chaurasia, vol-2, Edited by Krishna Garg, chapter- 16, Edition $7^{\text {th }}$, published by CBS publishers and distributors.

6. https://en.wikipedia.org/wiki/Development_of_the_digestive_system.

\section{Source of Support: Nil \\ Conflict of Interest: None Declared}

How to cite this URL: Shipra Katiyar: Comprehensive Study Of Nabhi In Bruhatrayi And Its Correlation With Modern Science. International Ayurvedic Medical Journal \{online\} 2021 \{cited March, 2021\} Available from: http://www.iamj.in/posts/images/upload/2837 2842.pdf 